\title{
PARADIGMA HUMANISME PENDIDIKAN ISLAM PADA ANAK USIA DINI
}

\author{
Indah Wigati dan Muhtarom
}

\author{
Program Studi PIAUD Fakultas Ilmu Tarbiyah dan Keguruan UIN Raden Fatah \\ email : muhtarom84@yahoo.com
}

\begin{abstract}
Humanisme dalam pendidikan Islam merupakan proses humanisasi yang memperhatikan keunikan yang ada pada diri manusia. Karena keunikan manusia itu, dapat dibangun basis fundamental pembelajaran anak. Dengan demikian pendidikan Islam dituntut untuk dapat memperhatikan keunikan yang ada pada anak tersebut sehingga akan menjadikan pendidikan Islam lebih bermakna karena mempertimbangkan kondisi personal anak secara menyeluruh. Anak usia dini memiliki motivasi diri yang dimilikinya sejak lahir untuk menjadi mampu. Motivasi berkemampuan inilah yang kemudian dipandang sebagai dasar untuk mengembangkan pembelajaran yang berepusat pada anak, dengan menghargai seluruh proses perkembangan yang dimiliki oleh anak dan berkembang sesuai dengan ritme yang dimiliki masing-masing anak, dengan menciptakan lingkungan dan menyediakan peralatan yang menyediakan kesempatan pada anak untuk belajar dan berkembang.
\end{abstract}

Kata Kunci: Humanisme, Pendidikan Islam, Anak Usia Dini

\section{Pendahuluan}

Manusia merupakan makhluk yang multidimensi bukan saja karena manusia sebagai subyek yang secara teologis memiliki potensi untuk mengembangkan pola kehidupan, tetapi juga sekaligus menjadi obyek dalam keseluruhan macam dan bentuk aktivitas dan kreativitasnya.

Dalam Islam, kita mengenal istilah fitrah pada manusia hal ini ditegaskan dalam hadist Nabi Muhammad SAW yang artinya: Tidak seorangpun dilahirkan kecuali mempunyai fitrah, maka kedua orangtuanya yang menjadikannya Yahudi, Nasrani dan Majusi”. (HR. Muslim). (Syeikh Manshur Ali Nashif, $1961 ; 36)$

Hadist di atas memberikan penjelasan bahwa seorang manusia lahir dalam keadaan fitrah, yakni dibekali naluri keagamaan tauhid. Tidak seorangpun bayi yang lahir ke dunia membawa dosa asal. Fitrah manusia merupakan potensi dasar yang baik yang perlu diasah dan dikembangkan. Kegiatan mengasah dan mengembangkan fitrah melalui proses transformasi nilai itu 
berlangsung dari generasi tua kepada generasi yang lebih muda. Dalam terminologi yang praktis, hal itu dinamakan pendidikan dalam makna yang luas.

Kemudian ayat Al-Qur'an menjelaskan yang artinya : Dan Allah mengeluarkan kamu dari perut ibumu dalam keadaan tidak mengetahui sesuatupun dan dari memberi kamu pendengaran, penglihatan dan hati agar kamu bersyukur" (Q.S. Al-Nahl, 16: 78).

Dalam pernyataan Al-Qur'an di atas, dapat dibingkai sebuah pengertian bahwa manusia dilahirkan dengan membawa potensi yang bisa dikembangkan (fitrah) seperti dalam hadist yang telah dijelaskan di atas yang diriwayatkan oleh Muslim dari Abu Hurairah di muka -dan manusia dilahirkan dengan tidak membawa pengetahuan apapun. Namun demikian, manusia dibekali alat untuk mencapai pengetahuan seperti indra pendengaran, penglihatan, dan hati. (Baharudin Moh, 2007;105-107)

Ada sebagian para ahli mengatakan bahwasannya watak manusia itu "berkembang" sesuai dengan perkembangan pribadi dan lingkungan yang melingkupinya. Hal itulah yang mengindikasikan bahwa sifat dan pembawaan, termasuk di didalamnya watak dan insting pada anak-anak itu berbeda-beda. Karena itu dapat dikatakan bahwa kewajiban seorang pendidik bila hendak memilihkan bidang pekerjaan buat seorang anak, meneliti terlebih dahulu sifat-sifatnya dan menguji kepintarannya kemudian dipilihkan jurusan pekerjaan yang sesuai.

Perbedaan sifat pembawaan, watak dan insting manusia tidak dapat dipisahkan dari pengaruh lingkungannya. Dengan pengaruh itu seluruh kondisi batin di atas dapat berkembang, bisa menjadi baik, bisa pula sebaliknya, menjadi buruk.

Dengan demikian, lingkungan dimana manusia itu berada berpengaruh besar bagi hidup dan perkembangan kehidupannya, mampu membentuk watak, kebiasaan, dan kecenderungan-kecenderungannya.

Jika lingkungannya baik, dapat memotivasi untuk mendatangkan pengaruh yang baik, sebaliknya, jika lingkungannya buruk, tak seorang (ulama') pun mampu membendung atau membantu akses buruknya. Sebenarnya manusia itu lahir dalam keadaan fitrah yaitu pembawaan asal 
untuk siap menerima agama Islam. Kemudian lingkungan mempengaruhinya untuk menjadi baik atau buruk. Untuk mengendalikan dan mengarahkan pengaruh tersebut, pendidikan berperan aktif.

Menurut pendapat al-Ghazali bahwasannya sejak kecil anak itu dapat menerima pengaruh baik atau buruk dari lingkungannya. Padahal di usia tersebut, anak tidak mampu membedakan antara baik dan buruk. Pendidikan orang tua, sebagai pihak pertama yang berinteraksi dengan anak, akan mampu mengendalikan dan mengarahkan pengaruh misieu.

Nabi Muhammad SAW bersabda yang artinya :"Tiap anak dilahirkan dalam keadaan fitrah kedua orang tuanyalah yang menjadikan anak tersebut menjadi Yahudi, Nasrani atau Majusi".

Dari uraian di atas bahwasannya watak manusia itu berkembang. Yang membedakan adalah konsep fitrah itu sendiri. Fitrah adalah pembawaan manusia yang tetap. Semua orang yang dilahirkan dengan pembawaan asal berupa fitrah tersebut, seumur hidupnya manusia memilikinya tidak ada perubahan dalam fitrah Allah yang dikaruniakan kepada hambanya (Q.S. 50: 50).

Oleh karena itu usaha-usaha pendidikan bagi manusia menjadi suatu kebutuhan pokok guna menunjang pelaksanaan amanat yang dilimpahkan Allah kepadanya. Ini merupakan kebutuhan manusia terhadap pendidikan yang bersifat individual. Kalau diamati keadaan bayi pada saat dilahirkan, dapat disaksikan bahwa mereka dalam keadaan yang sangat lemah, tidak berdaya. Hampir semua hidupnya tergantung pada orang tuanya. Mereka sangat memerlukan pertolongan dan bantuan orang tuanya dalam segala hal.

Demikian pula, jika dia tidak diberi bimbingan atau pengetahuan, baik jasmaniah maupun ruhaniah berupa pendidikan intelek, susila, sosial agama, dan sebagainya. Maka anak tersebut tidak akan dapat berbuat sesuatu secara maksimal. Dari sini jelaslah bahwa manusia dalam rangka melaksanakan tugas kehidupannya sangat membutuhkan apa yang disebut pendidikan, dengan demikian pendidikan menjadi kebutuhan pokok bagi manusia. Jadi manusia memerlukan pendidikan. 


\section{Pendidikan Islam}

Pendidikan adalah upaya sadar dalam rangka mewujudkan dan membentuk pribadi manusia seutuhnya, pendidikan adalah sebuah proses menciptakan pribadi manusia yang berguna bagi masyarakat, agama dan bangsa serta bertaqwa kepada Tuhan Yang Maha Esa. (Ngalim Purwanto, 2002; 27)

\section{Pendidikan yang dimiliki}

seseorang sangat menentukan, sekaligus dapat mewarnai perjalanan hidup untuk menggapai masa depannya, semakin tinggi pendidikan seseorang, dia akan lebih paham akan realitas, sehingga dia dapat menjalani dan melalui hidup ini dengan mudah. Adapun mereka yang pendidikannya di bawah rata-rata akan sulit dalam memahami realitas kehidupan. Hal itu menyebabkan dia kesulitan dalam menentukan masa depan.

Pada hakekatnya pendidikan adalah kebutuhan dasar (basic need) hidup manusia. Pendidikan juga merupakan salah satu bagian dari hak asasi manusia. Dalam pengertian lebih luas, pendidikan bertujuan untuk memberikan kemerdekaan kepada manusia dalam mempertahankan hidupnya. (Firdaus M. Yunus; 2004;7)

Selain itu, pendidikan secara umum dapat di pahami sebagai proses pendewasaan sosial manusia menuju pada dataran ideal. Makna yang terkandung di dalamnya menyangkut tujuan memelihara dan mengembangkan fitrah serta potensi atau sumber daya insani menuju terbentuknya manusia seutuhnya (insan kamil), (Achmad: 1992: 16). Penghargaan terhadap kebebasan untuk berkembang dan berpikir maju tentu saja sangat besar, mengingat manusia merupakan makhluk yang berpikir dan memiliki kesadaran. Praktek-praktek pendidikan pun harus senantiasa mengacu pada eksistensi manusia itu sendiri. Dari situ akan terbentuk mekanisme pendidikan yang demokratis yangberorientasi pada memanusiakan manusia. (Moh. Hanif Dhakiri. 2000;3)

Pendidikan dalam ejawantahnya membutuhkan sebuah landasan pijak dan paradigma yang mampu mengantarkan pada substansi apa yang akan dibawa dalam proses pendidikan tersebut, yakni mencakup persoalan-persoalan filosofis dalam arti luas. Persoalan filosofis tersebut 
menyangkut pertanyaan mendasar seperti apakah pendidikan itu?, Apakah tujuan dari pendidikan itu? Dari sinilah, filsafat sebagai sebuah paradigma pendidikan menemukan arti pentingnya dalam mengantarkan proses pendidikan yang mengantarkan pada pemanusiaan atau "Humanisasi" dalam arti yang sebenarnya. (Ahmad sudiarja, 2006;6) Pertanyaan kemudian adalah bagaimana dengan pendidikan Islam? Apa yang menjadi landasan pijak maupun paradigma yang digunakannya? Serta bagaimana penerapan konsep humanisasi pada anak usia dini?

\section{Pada hakekatnya pendidikan} Islam mengorientasikan pada pembentukan dan penempatan manusia sebagai makhluk 'Ahsanutaqwim' atau Insan Kamil yang pada perkembangan kehidupannya mampu menerjemahkan ajaran-ajaran Islam secara kontekstual serta tetap konsisten dalam membawa misi pencerdasan dan pembebasan hingga pada akhirnya manusia akan mencapai posisi sebagai 'kholifatullahu fil ardzi' yang sesuai dengan fitrahnya. Itu artinya, proses pendidikan harus mampu berorientasi pada keseimbangan dan proporsionalitas pengembangan pribadi manusia sebagai makhluk ciptaan Tuhan yang harus tunduk dan mengabdi pada-Nya serta mampu menjaga sesuatu yang diamanatkanNya dimuka bumi ini (Abdullah dan Kholifatullah) maupun pengembangan potensi yang seimbang dalam menjaga hubunganya dengan Sang Pencipta serta sesama manusia (Hablum Minallah dan Hablum Min Annas). Jadi, pendidikan pada khakekatnya adalah suatu proses untuk mencapai tujuan bahwa manusia di dunia ini adalah menjalankan amanah Allah SWT sebagai khalifah

Sementara itu, pendidikan Islam oleh Hassan Langgulung sebagaimana dikutip Azyumardi Azra merupakan suatu proses penyiapan generasi muda, memindahkan pengetahuan dan nilai-nilai Islam yang diselaraskan dengan fungsi manusia sebagai khalifah fil ardl untuk beramal di dunia dan memetik hasilnya di akherat. (Azyumardi Azra, 1998:5)

Dengan demikian, pada hakekatnya pendidikan adalah suatu proses "humanisasi" (memanusiakan manusia) yang mengandung implikasi bahwa tanpa pendidikan, manusia tidak akan menjadi manusia dalam arti 
yang sebenarnya. (Ahmad Ludjito, 1996;21). Dalam pendidikan Islam, muara pembentukan manusia mencakup dimensi imanesi (horizontal) dan dimensi transendensi (vertikal) (M. Rusli Karim, 1991, 31). Oleh karena itu, aspek mendasar dari pendidikan Islam adalah upaya melahirkan Insan Kamil.

Namun hingga saat ini menurut Sulaeman, pendidikan belum mampu mencapai titik idealnya yakni memanusiakan manusia, yang terjadi justru sebaliknya, yakni menambah rendahnya derajat manusia. Eksistensi yang sebenarnya menjadi hak milik secara mutlak untuk survive dan mengendalikan hidup, ternyata hilang dan kabur bersama arus yang menerpanya. Makna pendidikan yang belum terealisasikan ini menurutnya terkait dengan situasi sosiohistoris dan kondisi lingkungan yang melingkupinya. Seperti halnya penjajahan yang dilakukan Barat terhadap bangsa Indonesia selama berabad-abad ternyata membawa dampak yang sangat serius terhadap pola pikir dunia pendidikan, sehingga amat berpengaruh juga terhadap proses pendidikan yang berlangsung. Salah satu dampak yang paling buruk dari kolonialisme yang telah melanda negara jajahan-bukan Indonesia saja melainkan semua negara jajahan khususnya negara-negara Islam adalah dengan munculnya sebuah masyarakat kelas "elit" yang lebih tepat disebut sebagai "anak-anak yang tertipu". Produk dari sistempendidikan (Barat) yang "mengagumkan" ini didesain untuk membentuk sebuah kelas yang tercerabut dari tradisi budaya dan moralnya (Sulaiman, 2000: 81).

Sehingga para elit yang terbaratkan, yang tercerabut dari akar budayanya melihat Barat dengan rasa kagum yang teramat besar. Akibatnya, mereka membuang jauh-jauh budaya yang humanis untuk diganti dengan budaya materialis dan hedonis. Yang makna keber-Tuhanannya tidak lagi terealisasikan dalam tindak dan perilaku sehari-harinya (Sulaiman, 2000: 83-89).

Rangkaian uraian di atas menggambarkan bahwa pendidikan yang berlangsung sampai saat ini dapat dinilai belum mampu menyadarkan manusia akan dirinya. Sehingga pendidikan tidak dapat memberikan kontribusi kepada manusia untuk meningkatkan derajatnya, yaitu tetap eksis dan 
berada di depan dalam membawa segala perubahan. Padahal pendidikan seharusnya telah menampakkan hasil yang memuaskan, tatkala manusia sudah semakin yakin bahwa pendidikan adalah institusi yang mampu membentuk karakter-karakter manusia yang ditandai dengan semakin tumbuh dan berkembangnya potensi dasar manusia tersebut. Sehingga manusia dapat mengenal dirinya sendiri, alam dan Tuhannya. Hal ini dikarenakan potensi yang dimiliki manusia bukan hanya sekedar potensi dalam hal minat-bakat dan berfikir, tapi yang lebih luas lagi yaitu potensi bermasyarakat dan beragama.

Kondisi pendidikan yang belum mampu menjadi fasilitator menuju pengembangan potensi tersebut, diperkara lagi oleh sosialpolitik yang mengitarinya. Pendidikan kita justru digunakan sebagai alat indoktrinasi berbagai kepentingan, baik kepentingan politik yang akhirnya menuju pada pelanggengan kekuasaan, ilmu pengetahuan dan teknologi yang melampaui batas sehingga menggeser dan tidak menghargai eksisitensi manusia maupun kepentingan agama dengan sentimen-sentimennya untuk mengklaim dirinya sebagai satusatunya agama yang benar dan menganggap agama lain salah tanpa disertai sikap inklusif dan pluralis, yang pada gilirannya menjadikan agama rawan konflik.

Dalam kondisi demikian, pendidikan Islam ditantang untuk dapat mengembalikan posisi distortif nilai kemanusiaan yang terjadi. Pendidikan Islam harus mampu berperan sebagai instuti pematangan humanisasi baik sebagai individu maupun sebagai anggota masyarakat. Tugas untuk mengembalikan pergeseran nilai-nilai kemanusiaan yang terjadi tersebut merupakan tugas yang urgen. Permasalahannya adalah paradigma pendidikan Islam yang bagaimana yang dapat menjalankan tugas tersebut. Sedangkan pendidikan Islam yang selama ini sering dibidik orang sebagai pabrik intelektual yang mampu melahirkan pelaku-pelaku pembangunan yang tangguh, seringkali tidak berhasil mengelola dan memproduksi potensi kemanusiaan lainnya, termasuk yang berbasis batiniyah.

\section{Humanisme}

Humanisme secara etimologi, Dalam Ensiklopedi agama dan filsafat 
yang ditulis oleh Mokhtar Effendi berasal dari kata humanus yang artinya kemanusiaan, nama suatu aliran kebudayaan dikalangan pelajar yang mencapai puncaknya pada abad ke-15 di Italia, bertujuan mencari pengembangan segi rokhaniyah pada manusia secara mandiri. Humanisme (modern) diartikan sebagai pandangan hidup yang ingin memahami manusia dan kemanusiaan sebagai dasar dan tujuan dari segala dasar ilmu pengetahuan, kebudayaan dan agama. (Mochtar Effendy, 2001, 353)

Sejak abad ke-20an, konsep humanisme merupakan konsep kemanusiaan yang sangat berharga, karena konsep ini sepenuhnya memihak pada prinsip kemanusiaan, menjunjung tinggi harkat dan martabatnya, memfasilitasi pemenuhan kebutuhan-kebutuhan manusia untuk memelihara dan menyempurnakan keberadaannya sebagai makhluk paling mulia

Humanisme dalam Islam berarti secara otomatis membincang tentang humanisme religius, humanisme dalam Islam tidak bisa lepas dari konsep hablum minannas. Manusia hidup di bumi ini tidak lain mengemban amanat Tuhan sebagai
khalifah-Nya yang memiliki seperangkat tanggungjawab, dalam hal ini tanggungjawab tersebut lebih ditekankan pada tanggungjawab sosial dan tanggungjawab lingkungan hidup.

Ismail Raji Al Faruqi dalam buku berjudul Tauhid; Its Implications for Thought and Life, yang diterjemahkan oleh Rahmani Astuti menjelaskan bahwa Allah swt, dengan segala sifatnya yang welas asih dan bertujuan, tidaklah menciptakan manusia untuk main-main atau dengan sia-sia. Firman Allah dalam Q.S. Ali Imron ; 191 : terjemahanya .

Teori humanistik adalah suatu teori yang bertujuan memanusiakan manusia. artinya perilaku tiap orang ditentukan oleh orang itu sendiri dan memahami manusia terhadap lingkungan dan dirinya sendiri. Seperti halnya dalam Paradigma pendidikan humanistik memandang manusia sebagai "manusia", yakni makhluk ciptaan Tuhan dengan fitrah-fitrah tertentu. (Baharuddin, dan Moh. Makin, 22)

Para humanis cenderung untuk berpegang pada prespektif optimistik tentang sifat alamiah manusia. Mereka berfokus pada kemampuan manusia untuk berfikir secara sadar dan 
rasional dalam mengendalikan hasrat biologisnya, serta dalam meraih potensi maksimal mereka. Dalam pandangan humanistik, manusia bertanggung jawab terhadap hidup dan perbuatannya serta mempunyai kebebasan dan kemampuan untuk mengubah sikap dan perilaku mereka.

Manusia-manusia di sini adalah setiap individu yang hidup di dunia ini secara sadar. Dan setiap individu tersebut mempunyai hak-hak yang tidak dapat dilepaskan dari dirinya. Seperti hak untuk tumbuh berkembang. Individu tersebut dalam proses pendidikan disebut guru dan siswa, yang menurut aliran humanistik keduanya merupakan subjek pendidikan.

\section{Humanisme dan Pendidikan Islam}

Secara teorietis, humanisasi dalam kehidupan manusia sangat berkaitan erat dengan gelombang demokratisasi kehidupan manusia pada akhir dekade 80-an. Inti kehidupan demokrasi ialah penghormatan kepada nilai-nilai kemanusiaan. Tanpa penerapan asas demokrasi tidak mungkin kreativitas manusia yang menjadi sumber bagi peningkatan hidup manusia dapat hidup dan berkembang. (H.A.R. Tilaar, 2001, 4-5)

Oleh karena itu, humanisasi dalam dunia pendidikan menuntut proses pendidikan yang lebih memperhatikan pengembangan kreativitas dalam kepribadian anak sebagai inti dari kehidupan demokratis yang sangat menghormati nilai-nilai kemanusiaan (H.A.R. Tilaar, 2001, 45). Jadi, gerakan humanisasi dalam dunia pendidikan merupakan sebuah usaha yang lebih. mementingkan nilainilai kemanusiaan dalam proses pendidikan.

Pendidikan dituntut untuk lebih memperhatikan pengembangan kreativitas dalam kepribadian anak. Humanisme dimaknai sebagai potensi (kekuatan) individu untuk mengukur dan mencapai ranah ketuhanan serta mampu menyelesaikan persoalanpersoalan sosial. Sementara itu, pendidikan Islam merupakan suatu proses dalam membentuk manusia sesuai dengan cita-cita Islam.

Dengan demikian, humanisme dalam dunia pendidikan Islam merupakan proses pendidikan yang lebih memperhatikan aspek potensi manusia sebagai makhluk berketuhanan dan makhluk 
berkemanusiaan serta individu yang diberi kesempatan oleh Allah untuk mengembangkan potensi-potensinya (Abdurrahman Mas'ud, 135).

\section{Pendidikan Anak Usia Dini}

Pendidikan anak usia dini (PAUD) adalah jenjang pendidikan sebelum jenjang pendidikan dasar yang merupakan suatu upaya pembinaan yang ditujukan bagi anak sejak lahir sampai dengan usia enam tahun yang dilakukan melalui pemberian rangsangan pendidikan untuk membantu pertumbuhan dan perkembangan jasmani dan rohani agar anak memiliki kesiapan dalam memasuki pendidikan lebih lanjut, yang diselenggarakan pada jalur formal, nonformal, dan informal.

Pendidikan anak usia dini merupakan salah satu bentuk penyelenggaraan pendidikan yang menitikberatkan pada peletakan dasar ke arah pertumbuhan dan perkembangan fisik (koordinasi motorik halus dan kasar), kecerdasan (daya pikir, daya cipta, kecerdasan emosi, kecerdasan spiritual), sosio emosional (sikap dan perilaku serta agama) bahasa dan komunikasi, sesuai dengan keunikan dan tahap-tahap perkembangan yang dilalui oleh anak usia dini.

$$
\text { Ada dua tujuan }
$$
diselenggarakannya pendidikan anak usia dini yaitu: 1. Tujuan utama: untuk membentuk anak Indonesia yang berkualitas, yaitu anak yang tumbuh dan berkembang sesuai dengan tingkat perkembangannya sehingga memiliki kesiapan yang optimal di dalam memasuki pendidikan dasar serta mengarungi kehidupan pada masa dewasa. 2. Tujuan penyerta: untuk membantu menyiapkan anak mencapai kesiapan belajar (akademik) di sekolah.

Rentangan anak usia dini menurut Pasal 28 UU Sisdiknas No. 20/2003 ayat 1 adalah 0-6 tahun. Sementara menurut kajian rumpun keilmuan PAUD dan penyelenggaraannya di beberapa negara, PAUD dilaksanakan sejak usia 0-8 tahun.

Ruang Lingkup Pendidikan Anak Usia Dini; 1. Infant (0-1 tahun), 2. Toddler (2-3 tahun), 3. Preschool/ Kindergarten children (3-6 tahun), 4. Early Primary School (SD Kelas Awal) (6-8 tahun).

$$
\text { Landasan }
$$

Filosofis

Pelaksanaan pembelajaran pada Anak 
Usia Dini juga merupakan implementasi dari kurikulum yang berlaku. Pada saat mempertimbangkan pelaksanaan pembelajaran ini didasari pada landasan filosofis, landasan psikologis, dan landasan yuridis. Menurut Sukayati (2004:4), landasan filosofis dari implementasi pembelajaran pada anak usia dini sangat dipengaruhi oleh tiga aliran filsafat yaitu: (1) progresivisme, (2) konstruktivisme, dan (3) humanisme.

Teori humanistik memandang tujuan belajar adalah untuk memanusiakan manusia. Proses belajar dianggap berhasil jika peserta didik memahami lingkungannya dan dirinya sendiri. Siswa dalam proses belajarnya harus berusaha agar lambatlaun ia mampu mencapai aktualisasi diri dengan sebaik-baiknya. Teori belajar ini berusaha memahami perilaku belajar dari sudut pandang pelakunya, bukan dari sudut pandang pengamatnya. Tujuan utama para pendidik adalah membantu si siswa untuk mengembangkan dirinya, yaitu membantu masing-masing individu untuk mengenal diri mereka sendiri sebagai manusia yang unik dan membantu dalam mewujudkan potensi-potensi yang ada dalam diri mereka. Para ahli humanistik melihat adanya dua bagian pada proses belajar, ialah : Proses pemerolehan informasi baru, Personalia informasi ini pada individu. Tokoh penting dalam teori belajar humanistik secara teoritik antara lain adalah: Arthur W. Combs, Abraham Maslow dan Carl Rogers. Arthur Combs (1912-1999) Bersama dengan Donald Snygg (1904-1967) mereka mencurahkan banyak perhatian pada dunia pendidikan. Meaning (makna atau arti) adalah konsep dasar yang sering digunakan. Belajar terjadi bila mempunyai arti bagi individu. Guru tidak bisa memaksakan materi yang tidak disukai atau tidak relevan dengan kehidupan mereka. Anak tidak bisa matematika atau sejarah bukan karena bodoh tetapi karena mereka enggan dan terpaksa dan merasa sebenarnya tidak ada alasan penting mereka harus mempelajarinya. Perilaku buruk itu sebenarnya tak lain hanyalah dati ketidakmampuan.

Abraham H. Maslow dikenal sebagai salah satu tokoh psikologi humanistik. Karyanya di bidang ini berpengaruh dalam upaya memahami motivasi manusia. la menyatakan bahwa dalam diri manusia terdapat 
dorongan positif untuk tumbuh sekaligus ke-kuatan yang menghambat.

Maslow mengatakan, mengatakan bahwa ada beberapa kebutuhan yang perlu dipenuhi oleh setiap manusia yang siratnya hierarkis. Pemenuhan kebutuhan dimulai dari kebutuhan terendah, selanjutnya meningkat pada kebutuhan yang lebih tinggi. Kebutuhan tersebut adalah. : Kebutuhan jasmaniah, Kebutuhan keamanan, Kebutuhan kasih sayang, Kebutuhan harga diri, Kebutuhan aktualisasi diri.

Lebih jauh Maslow mengatakan, hierarki kebutuhan manusia tersebut mempunyai implikasi penting bagi individu peserta didik. Oleh karenanya, pendidik harus memerhatikan kebutuhan peserta didik sewaktu beraktivitas di dalam kelas. Seorang pendidik dituntut memahami kondisi tertentu, misalnya, ada peserta didik tertentu yang sering tidak mengerjakan pekerjaan rumahnya, atau ada yang berbuat gaduh, atau ada yang tidak minat belajar. Menurut Maslow, minat atau motivasi untuk belajar tidak dapat berkembang jika kebutuhan pokoknya tidak terpenuhi. Peserta didik yang datang ke sekolah tanpa persiapan, atau tidak dapat tidur nyenyak, atau membawa persoalan pribadi, cemas atau takut, akan memiliki daya motivasi yang tidak optimal, sebab persoalan-persoalan yang dibawanya akan mengganggu kondisi ideal yang dia butuhkan.

Carl R. Rogers adalah seorang ahli psikologi humanis yang gagasangagasannya berpengaruh terhadap pikiran dan praktek pendidikan. la menyarankan adanya suatu pendekatan yang berupaya menjadikan belajar dan mengajar dalam arti proses pembelajaran di kelas hendaknya lebih manusiawi. Gagasan-gagasan Carl R. Rogers itu adalah:

Pertama, Hasrat untuk belajar : Menurut Rogers, manusia mempunyai hasrat untuk belajar. Hal itu mudah dibuktikan. Perhatikan saja, betapa ingin tahunya anak kalau sedang mengeksplorasi lingkungannya. Dorongan ingin tahu dan belajar merupakan asumsi dasar pendidikan humanistis. Di dalam kelas yang humanistis, peserta didik diberi kebebasan dan kesempatan untuk memuaskan dorongan ingin tahu dan minatnya terhadap sesuatu yang menurutnya bisa memuaskan kebutuhannya. Orientasi ini 
bertentangan dengan gaya lama, di mana seorang pendidik atau kurikulum mendominasi peta proses pembelajaran.

Kedua. Belajar yang berarti: Prinsip ini menuntut adanya relevansi antara bahan ajar dengan kebutuhan yang diinginkan peserta didik. Anak akan belajar jika ada hal yang berarti baginya. Misalnya, anak cepat belajar menghitung uang receh karena uang tersebut dapat digunakan untuk membeli barang kesukaannya.

Ketiga. Belajar tanpa ancaman: Belajar mudah dilakukan dan hasilnya dapat disimpan dengan baik apabila berlangsung dalam lingkungan yang bebas ancaman. Proses pembelajaran dapat berjalan dengan lancar ketika peserta didik dapat menguji kemampuannya, dapat mencoba pengalaman-pengalaman baru, atau membuat kesalahan-kesalahan tanpa mendapat kecaman yang menyinggung perasaannya. Jika kenyamanan sudah dia dapatkan, pembelajaran pun akan menjadi kondusif. Anak tidak merasa tertekan dan pendidik dianggapnya sebagai fasilitator yang menyenangkan.

Keempat. Belajar atas inisiatif sendiri : Bagi para humanis, belajar akan sangat bermakna ketika dilakukan atas inisiatif sendiri. Peserta didik akan mampu memilih arah belajarnya sendiri, sehingga memiliki kesempatan untuk menimbang dan membuat keputusan serta menentukan pilihan dan introspeksi diri. Dia akan bergantung pada dirinya sendiri, sehingga kepercayaan dirinya menjadi lebih baik.

Kelima. Belajar dan perubahan: Prinsip terakhir yang dikemukakan Rogers adalah bahwa belajar paling bermanfaat adalah belajar tentang proses belajar. Menurutnya, di waktu lampau peserta didik belajar mengenal fakta-fakta dan gagasan-gagasan yang statis, dan apa yang didapat di sekolah dirasa sudah cukup untuk kebutuhan saat itu. Tetapi sekarang, tuntutan mengubah pola pikir yang datang setiap waktu. Apa yang dipelajari di masa lalu tidak dapat mudah dijadikan pegangan untuk mencapai sukses di masa sekarang ini. Apa yang dibutuhkan sekarang adalah orang-orang yang mampu belajar di lingkungan yang sedang berubah dan terus akan berubah. Aliran dan teori pendidikan ini menjadi warna yang dominan di dunia pendidikan. Meski tidak dianut 
seluruhnya, minimal ada aliran yang diikuti dan teori yang digunakan sebagai upaya pengembangan pendidikan.

\section{Aspek-Aspek Kemanusiaan \\ Pembelajaran Humanistik Pada Anak Usia Dini}

Manusia adalah makhluk
multidimensional yang memiliki
berbagai macam potensi. Howard
Gardner (dalam Chatib 2009: 56)
menelaah manusia dari sudut
kehidupan mentalnya, khususnya
aktivitas intelegensianya. Menurutnya
manusia memiliki 9 macam
kecerdasan yaitu:

\section{Pertama.}

Kecerdasan

linguistik. Komponen inti kecerdasan ini adalah kepekaan pada bunyi, struktur, makna, fungsi kata dan bahasa. Kecerdasan ini berkaitan dengan kemampuan membaca, menulis, berdiskusi, berargumentasi, berdebat.

Kedua. Kecerdasan Matematis -Logis Komponen inti kecerdasan jenis adalah kepekaan kepada memahami pola-pola logis atau numeris, dan kemampuan mengolah alur pemikiran yang panjang. Kecerdasan ini berkaitan dengan kemampuan berhitung, menalar, dan berpikir logis, memecahkan masalah.

Ketiga. Kecerdasan VisualSpasial. Komponen inti kecerdasan ini adalah kepekaan merasakan dan membayangkan dunia gambar dan ruang secara akurat. Kecerdasan ini berkaitan dengan kemampuan menggambar, memotret, membuat patung dan mendesain.

Keempat. Kecerdasan Musikal. Komponen inti kecerdasan ini adalah kepekaan dan kemampuan menciptakan dan mengapresiasikan irama, pola titi nada dan warna nada serta apresiasi bentuk-bentuk ekspresi emosi musikal. Kecerdasan ini berkaitan dengan kemampuan menciptakan lagu, mendengar nada dari sumber bunyi atau alat-alat musik.

Kelima. Kecerdasan Kinestetis. Kompenen inti kecerdasan jenis ini adalah kemampuan mengontrol gerak tubuh dan kemahiran mengola objek, respons dan refleks. Kecerdasan ini berkaitan dengan kemampuan gerak motorik dan keseimbangan.

Keenam. Kecerdasan Interpersonal. Kompenen inti kecerdasan ini adalah kepekaan mencerna dan merespons secara tepat suasana hati, temperamen, motivasi 
dan keinginan orang lain. Kecerdasan ini berkaitan dengan kemampuan bergaul dengan orang lain, memimpin, kepekaan sosial yang tinggi, negosiasi, bekerjasama, dan mempunyai empati yang tinggi.

Ketujuh. Kecerdasan

Intrapersonal. Komponen inti kecerdasan ini adalah memahami perasaan sendiri dan kemampuan membedakan emosi, pengetahuan tentang kekuatan dan kelemahan diri.kecerdasan ini berkaitan dengan kemampuan mengenali diri secara mendalam, kemampuan intuitif dan motivasi diri, penyendiri, sensitive terhadap nilai diri dan tujuan hidup.

Kedelapan. Kecerdasan Naturalis. Komponen inti kecerdasan ini adalah keahlian membedakan anggota-anggota spesies, mengenali eksistensi spesies lain, dan memetakan hubungan antara beberapa spesies baik secara formal maupun non-formal. Kecerdasan ini berkaitan dengan kemampuan meneliti gejala-gejala alam, mengklasifikasi dan identifikasi.

Kesembilan. Kecerdasan Eksistensialis. Bentuk kecerdasan ini adalah kemampuan untuk memberikan nasehat dan pertimbanagn tentang hidup. Anak dengan kecerdasan ini, berpotensi menjadi ustad, psikolog atau orang yang bisa memberikan solusi terhadap permasalahan orang.

\section{Penutup.}

Konsep dan tujuan humasine pendidikan Islam pada dasarnya adalah pendidikan yang memanusiakan manusia yaitu pendidikan yang menghargai, menggali, melayani, membantu anak untuk mengembangkan berbagai macam potensi yang dimiliki oleh siswa. Sedangkan tujuannya adalah untuk mengembangkan berbagai macam potensi yang dimiliki oleh siswa menjadi generasi yang cerdas, religius, dan berakhlakul karimah.

\section{Daftar Pustaka}

Arifin, Muhamad, Ilmu Pendidikan Islam, Jakarta : Bumi Aksara, 2000.

Arifin, Zainul, "Islam dan Humanisme ; Upaya Sintesa Dialektis Antara Perspektif Sekuler dan Agama Tentang Otoritas Manusia Dalam Tatanan Kosmik Transendental" dalam Jurnal STAIN Malang, Edisi 6, Malang,

Baharudin Moh. Makin, Pendidikan Humanistik , (Jogjakarta: ArRuzz Media, 2007) 
Boisard, Marcel A. Humanisme Dalam Islam, (Jakarta: Bulan Bintang, 1980)

Baharuddin dan Moh Makin. 2011. Pendidikan Humanistik (konsep, teori, dan aplikasi praksis dalam dunia pendidikan). Yogyakarta: Ar Ruz Media.

Chatib, Munif. 2009. Sekolahnya Manusia. Bandung: Kaifa PT Mizan Pustaka.

2011. Gurunya Manusia. Bandung: Kaifa PT Mizan Pustaka.

Darajat, Zakiah, Ilmu Pendidikan Islam, Jakartaraja Grafindo Persada,

Fajar, Malik, Reorientasi Penidikan Islam, Jakarta : Fajar Dunia, 1999.

Firdaus M. Yunus, Pendidikan Berbasis Realitas Sosial, (Yogyakarta: Logung Pustaka, 2004)

Kasdu, Dini. 2004. Anak Cerdas. Jakarta: Puspa Suara Kelompok Penerbit IKAPI.

Mas'ud, Abdurrahman Intelektual Pesantren; Perhelatan Agama Dan Tradisi, Jogjakarta, Lkis, 2004).

, "Menuju Paradigma Islam Humanis" (Yogyakarta, Gama Media, 2003) Dan Madzhab Barat, terj Afif
Muhammad, Bandung; Pustaka Hidayah, 1996

Menggagas Format Pendidikan Nondikotomik (Humanisme ReligiusSebagai Paradigma Pendidikan Islam).

Mulkhan, Abdul Munir Kearifan Tradisional, Agama Bagi MAnusia atau Tuhan, (Yogyakarta: UII Press, 2000) , Nalar Spiritual: Solusi Problem Filosofis Pendidikan Islam, (Yogyakarta: Tiara Wacana, 2002) Rekonstruksi Pendidikan dan Tradisi Pesantren dalam Religiutas Iptek, (Yogyakarta: Pustaka Pelajar, 1998).

M. Dimyati Mahmud. Psikologi Pendidikan, (Jakarta: Departemen Pendidikan dan Kebudayaan, 1989),

Matt Jarvis, Teori-Teori Psikologi. Pendekatan Modern untuk Memahami Perilaku, Perasaan, dan Pikiran Manusia, (Bandung: Nusamedia dan Nuansa, 2007),

Moh. Hanif Dhakiri, Paulo Freire, Islam dan Pembebasan, (Jakarta: Djambatan bekerjasama dengan PENA, 2000)

Ngalim Purwanto, Ilmu Pendidikan; Teoritis dan Praktis, (Bandung: PT. Remaja Rosdakarya, 2002)

Purwanto, Ngalim, M. Drs., Ilmu Pendidikan; Teoritis dan 
Praktis, (Bandung: PT. Remaja Rosdakarya, 2002)

Samsul Ma'arif, Samsul M.Ag, Revitalisasi Pendidikan Islam, (Jogjakarta; Graha Ilmu, 2007)

Syariati, Ali, Humanisme Antara Islam Dan Madhab Barat, Terj Afif Muhammad, (Bandung: Pustaka Hidayah, 1996.

Sukardjo dan Ukim Komarudin. Landasan Pendidikan, Konsep dan Aplikasinya,(Jakarta: PT Raja rafindo Persada, 2009

Syeikh Manshur Ali Nashif, Al-Taj alJami' li al-Ushul fi al-Hadist al-Rasul, (Beirut: Dar Ihya' alTurast al-Araby, 1961 M $1381 \mathrm{H})$,

Sukayati, 2004, Pembelajaran Tematik di SD Merupakan Penerapan dari Pembelajaran terpadu, Yogyakarta, Depdiknas

Tresna Sastrawijaya. Proses Belajar Mengajar Diperguruan Tinggi, (Jakarta: 1988)

Hasbi As Shiddiqi, dkk., Al Qur'an dan terjemahnya, (Jakarta: Departemen Agama, 1971)

Zahara, Idris, Pengantar Pendidikan I, Jakarta,Grasindo,1992 